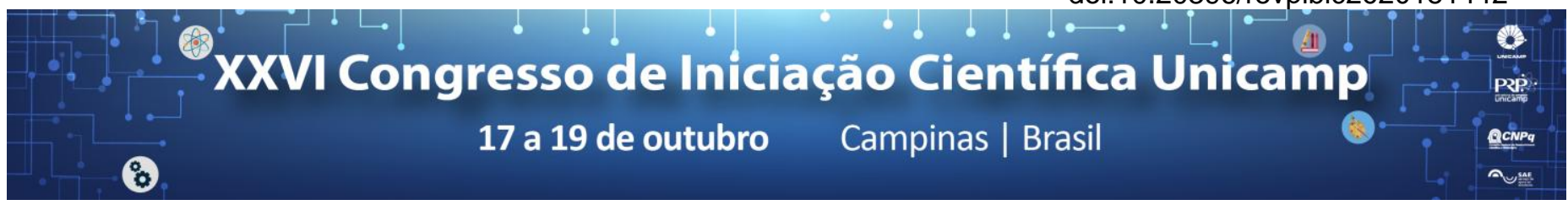

\title{
Estudo das moléculas de adesão celular em tumores tireoidianos
}

\section{Eve G. R. Bruno*, Luana M. P. Da Silva*, Savio S. Vellozo.*, Larissa Teodoro, Natássia E. Bufalo, Laura S. Ward.}

\section{Resumo}

O câncer de tireoide é a malignidade endócrina mais comum e é mais prevalente no sexo feminino. Desse modo, a procura por marcadores específicos se torna necessária para auxiliar tanto no diagnostico quanto no prognostico da doença. O projeto visa avaliar a expressão gênica e proteíca das moléculas de adesão celular (ICAM-1, LFA-1, LSelectina e PNAD) em tumores tireoidianos correlacionado ao desempenho da migração do linfocitária no endotélio vascular.

Palavras-chave: Câncer de tireoide, moléculas de adesão celular, migração linfocitária.

\section{Introdução}

O câncer de tireoide ocorre na glandula que se localiza em baixo da laringe, sendo mais comum a sua incidência no sexo feminino. As principais variantes são: o carcinoma papilífero - aproximadamente $80 \%$ dos casos, se desenvolve nas células foliculares, atingindo os gânglios linfáticos, e apresenta o melhor prognóstico dentre as demais neoplasias malignas tireoidianas, elevando as taxas de sua cura; o carcinoma folicular tende a ser $15 \%$ dos carcinomas responsável pelo câncer de tireoide, e o carcinoma anaplásico - representa $5 \%$ dos casos e é considerado o mais agressivo e instável dos cânceres de tireoide, podendo levar a morte.

As moléculas de adesão celular são glicoproteinas, expressas na superfície celular. São importantes para a migração dos leucócitos até o sitio injuriado. Esse processo ocorre em quatro principais fases: rolamento, ativação, adesão estável e, por fim, transmigração. As moléculas de adesão celular são classificadas, principalmente, em quatro famílias: as caderinas e as selectinas, integrinas e superfamília das imunoglobulinas. Neste projeto estudamos as moléculas: ICAM-1 - pertence à superfamília das imunoglobulinas, essa molécula possui afinidade com a molécula LFA-1 que pertence à família da integrinas; a molécula L-selectina - é uma molécula que pertence à família das selectinas, ela tem como inicio a atuação de captura das células imunes, e a molécula PNAd é o ligante direto da L-selectina.

O objetivo deste trabalho é avaliar a expressão gênica e proteica das moléculas de adesão celular em tumores tireoidianos e nosso papel nesse projeto foi aprender as técnicas utilizadas em sua execução.

\section{Resultados e Discussão}

Inicialmente é necessário realizar a coleta de TCLE e a separação de amostras dos casos que serão utilizados no trabalho. Os materiais utilizados devem ser lavados com Extran® $2 \%$ com 0 intuito de limpar os materiais de rotina do laboratório, após essa etapa é realizado o processo de esterilização úmida, esta é feita em autoclave, tornando os materiais aptos para serem submetidos às técnicas futuras.
Para a analise de expressão proteica é montado o TMA que será utilizado para a reação de imunoistoquímica na qual aplica-se sobre a lamina de TMA um anticorpo especifico para detectar as moléculas alvo.

Para a análise da expressão gênica, é necessário inicialmente realizar a extração de RNA de tecido parafinado, quantificação e diluição do RNA e posterior transcrição reversa para que se possa adquirir o cDNA a partir de uma molécula de RNAm, e por fim, realizar a técnica de RT-qPCR.

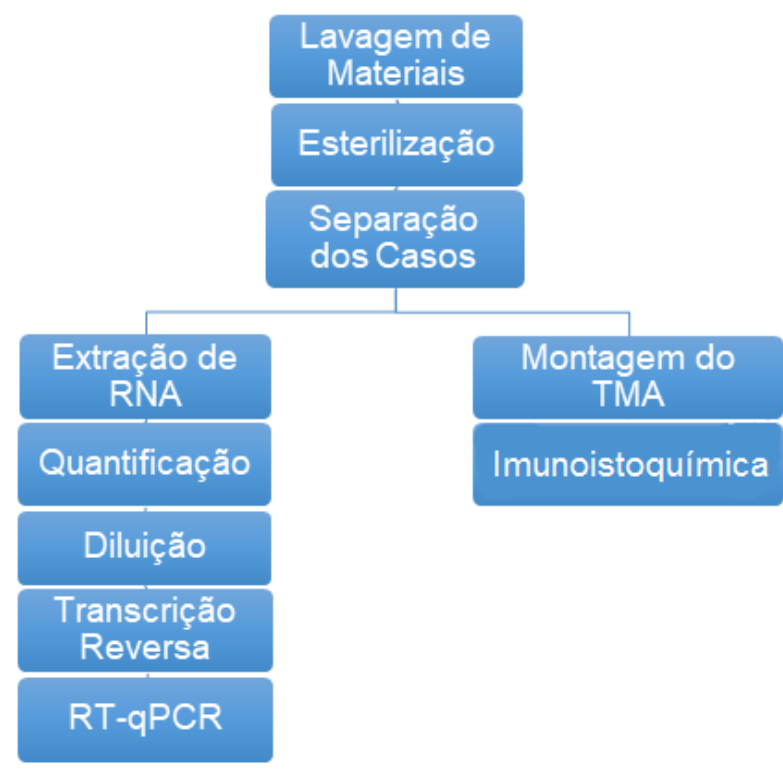

\section{Conclusões}

As experiências durante 2017-2018 no programa PIBIC-EM foram excepcionais, trazendo para nós uma nova perspectiva profissional e social.

\section{Agradecimentos} GEMOCA.

Nossos agradecimentos ao CNPq e ao laboratório

Instituto Nacional do Câncer - INCA. Câncer da tireoide. Disponível em <http://www.inca.gov.br/conteudo_view.asp?id=2187> Acesso em: 02 jul. 2018

PERES, A. J. Nova abordagem para tumor de tireoide. Jul/2016.Disponível em:

<http://www2.inca.gov.br/wps/wcm/connect/3e4e4c004dff1f45870fff4cb2154e0 6/12_RC34_epidemiologia.pdf?MOD=AJPERES> Acesso em: 30 jun. 2018. 